\title{
Manajemen Peningkatan Mutu Berbasis Sekolah untuk Peningkatkan Profesionalisme Guru Bimbingan dan Konseling/Konselor
}

\author{
Oleh : Drs. Arista Kiswantoro, M.Pd \\ Universitas Muria Kudus
}

\begin{abstract}
The profession of a guidance and counseling is not often strict by people who concern in the guidance and counseling such as students, teachers, headmasters, stake holders or even society. Many people still worry about the professionality of the counseling profession actors. There are many opinions consider that the profession of the guidance and counseling is not often strict. So, that is the challenge to make the profession of the guidance and counseling to be good and professional.

The use of MPMBS is used to improve the quality and quantity of guidance service. The counselor should give pay attention to the team work and coordination with the education components. In the MPMBS, the education successful in the school is not based on the individual intelligent but it focuses on team work intelligent. Furthermore, the counselors have to take the participation in the team work.

Keywords: MPMBS, guidance and counseling.
\end{abstract}

\begin{abstract}
ABSTRAK
Pekerjaan bimbingan dan konseling kerapkali dipandang sebelah mata oleh orang-orang yang justru memiliki kepentingan dengan bimbingan dan konseling itu sendiri, Misalnya, oleh siswa, guru mata pelajaran, kepala sekolah, para pemegang kebijakan lainnya dan atau masyarakat. Banyak kalangan yang masih mempertanyakan tentang kadar keprofesionalan para pelaku profesi konseling itu. Jangankan untuk setting masyarakat, di setting persekolahan tidak sedikit ditemukan pandangan-pandangan yang merendahkan tugas dan pekerjaan konselor sekolah. Semua itu tentu merupakan sesuatu yang seharusnya disikapi sebagai tantangan dalam upaya menegakkan kemartabatan profesi bimbingan dan konseling

Penerapan MPMBS, sebagai upaya meningkatkan kuantitas dan kualitas layanan bimbingan dan konselor hendaknya memperhatikan pengembangan kerja sama, koordinasi dan sinergis kerja dengan berbagai komponen pendidikan lainnya. Karena dalam MPMBS, keberhasilan pendidikan di sekolah tidak lagi didasarkan pada individual yang cerdas, akan tetapi sangat mengutamakan pada team work yang kompak.

Kata Kunci: MPMBS, Bimbingan dan Konseling
\end{abstract}

\section{PENDAHULUAN}

Pekerjaan bimbingan dan konseling sering dipandang sebelah mata oleh orang-orang yang justru memiliki kepentingan dengan bimbingan dan konseling itu sendiri, Misalnya, oleh siswa, guru mata pelajaran, kepala sekolah, para pemegang kebijakan lainnya dan atau masyarakat. Tidak sedikit mereka yang beranggapan bahwa guru Bimbingan dan Konseling di sekolah hanya makan gaji buta, dan tidak jelas kerjanya. Ungkapan-ungkapan semacam itu bisa ditepis jika guru Bimbingan dan Konseling dapat menunjukkan kinerjanya sekaligus mampu melakukan advokasi di hadapan mitra kerjanya di sekolah.

Banyak kalangan yang masih mempertanyakan tentang kadar keprofesionalan para pelaku profesi konseling. Jangankan untuk setting masyarakat, di setting sekolahpun tidak sedikit ditemukan pandangan-pandangan yang merendahkan tugas dan pekerjaan konselor sekolah. Semua itu tentu merupakan sesuatu yang seharusnya disikapi sebagai tantangan 
dalam upaya menegakkan kemartabatan profesi bimbingan dan konseling (Mugiarso,2008: $3)$.

Salah satu isu penting tentang pendidikan saat ini berkenaan dengan penerapan Manajemen Peningkatan Mutu Berbasis Sekolah (MPMBS) yang merupakan proses pengintegrasian, pengkoordinasian dan pemanfaatan dengan melibatkan secara menyeluruh elemen-elemen yang ada pada sekolah untuk mencapai tujuan (mutu pendidikan) yang diharapkan secara efisien. Atau dapat diartikan bahwa Manajemen Peningkatan Mutu Berbasis Sekolah (MPMBS) adalah model manajemen yang memberikan otonomi yang lebih besar kepada sekolah dan mendorong pengambilan keputusan yang partisipatif yaitu melibatkan semua warga sekolah berdasarkan kesepakatan bersama.

Dengan adanya otonomi yang lebih besar diharapkan sekolah memiliki kewenangan secara mandiri dalam mengelola sekolah dan memilih strategi dalam meningkatkan mutu pendidikan serta dapat memilih pengembangan program yang lebih sesuai dengan potensi kebutuhan daerah dimana lulusannya akan diproyeksikan. Konsep ini diperkenalkan oleh teori effective school yang lebih memfokuskan diri pada perbaikan proses pendidikan (Omaedi,1999: 4)

Dengan hadirnya Manajemen Peningkatan Mutu Berbasis Sekolah (MPMBS), yang mengedepankan pendekatan desentralistik-profesional, maka ruang gerak konselor menjadi leluasa. Proses kreatif dan inovatif justru menjadi lebih utama. Konselor didorong untuk memiliki keberanian dan membiasakan diri untuk menemukan cara-cara baru yang lebih efektif dan efisien dalam melaksanakan berbagai kegiatan pelayanan bimbingan dan konseling. Dengan kata lain, memasuki alam Manajemen Peningkatan Mutu Berbasis Sekolah (MPMBS), konselor dituntut bekerja secara profesional.

Penerapan (MPMBS), sebagai upaya meningkatkan kuantitas dan kualitas layanan bimbingan ini konselor hendaknya memperhatikan pengembangan kerja sama, koordinasi dan sinergis kerja dengan berbagai komponen pendidikan lainnya. Karena dalam penerapan Manajemen Peningkatan Mutu Berbasis Sekolah (MPMBS), keberhasilan pendidikan di sekolah tidak lagi didasarkan pada individual yang cerdas, akan tetapi sangat mengutamakan pada team work yang kompak.

\section{LANDASAN TEORI}

\subsection{Manajemen Peningkatan Mutu Berbasis Sekolah}

Manajemen peningkatan mutu berbasis sekolah merupakan alternatif baru dalam pengelolaan pendidikan yang lebih menekankan kepada kemandirian dan kreatifitas sekolah. Bervariasinya kebutuhan siswa akan belajar, beragamnya kebutuhan guru dan staf lain dalam pengembangan profesionalnya, berbedanya lingkungan sekolah satu dengan lainnya dan ditambah dengan harapan orang tua/masyarakat akan pendidikan yang bermutu bagi anak dan tuntutan dunia usaha untuk memperoleh tenaga bermutu, berdampak kepada keharusan bagi setiap individu harus mampu merespon dan mengapresiasikan kondisi tersebut di dalam proses pengambilan keputusan.

Ini memberi keyakinan bahwa di dalam proses pengambilan keputusan untuk peningkatan mutu pendidikan mungkin dapat dipergunakan berbagai teori, perspektif dan kerangka acuan dengan melibatkan berbagai kelompok masyarakat yang memiliki kepedulian kepada pendidikan. Karena sekolah berada pada pada bagian terdepan dari pada proses pendidikan, maka konsekwensinya bahwa sekolah harus menjadi bagian utama di dalam proses pembuatan keputusan dalam rangka peningkatan mutu pendidikan. Sementara, masyarakat dituntut partisipasinya agar memahami pendidikan, sedangkan pemerintah pusat berperan sebagai pendukung dalam hal menentukan kerangka dasar kebijakan pendidikan.

Strategi ini berbeda dengan konsep mengenai pengelolaan sekolah yang selama ini kita kenal. Dalam sistem lama, birokrasi pusat sangat mendominasi proses pengambilan atau pembuatan keputusan pendidikan, yang bukan hanya kebijakan bersifat makro saja tetapi lebih jauh kepada hal-hal yang bersifat mikro; Sementara sekolah cenderung hanya melaksanakan 
kebijakan-kebijakan tersebut yang belum tentu sesuai dengan kebutuhan belajar siswa, lingkungan Sekolah, dan harapan orang tua.

Pengalaman menunjukkan bahwa sistem lama seringkali menimbulkan kontradiksi antara apa yang menjadi kebutuhan sekolah dengan kebijakan yang harus dilaksanakan di dalam proses peningkatan mutu pendidikan. Fenomena pemberian kemandirian kepada sekolah ini memperlihatkan suatu perubahan cara berpikir dari yang bersifat rasional, normatif dan pendekatan preskriptif di dalam pengambilan keputusan pendidikan kepada suatu kesadaran akan kompleksnya pengambilan keputusan di dalam sistem pendidikan dan organisasi yang mungkin tidak dapat diapresiasiakan secara utuh oleh birokrat pusat. Hal inilah yang kemudian mendorong munculnya pemikiran untuk beralih kepada konsep manajemen peningkatan mutu berbasis sekolah sebagai pendekatan baru di Indonesia, yang merupakan bagian dari desentralisasi pendidikan yang tengah dikembangkan (Sudrajat, 2008: 2).

\section{A. Indikator Manajemen Peningkatan Mutu Berbasis Sekolah}

Manajemen peningkatan mutu berbasis sekolah merupakan alternatif baru dalam pengelolaan pendidikan yang lebih menekankan kepada kemandirian dan kreatifitas sekolah. Konsep ini diperkenalkan oleh Edmond dalam teori effective school yang lebih memfokuskan diri pada perbaikan proses pendidikan (dalam Umaedi, 1999: 4-5 ). Beberapa indikator yang menunjukkan karakter dari konsep manajemen ini antara lain sebagai berikut:

(i) lingkungan sekolah yang aman dan tertib

(ii) sekolah memilki misi dan target mutu yang ingin dicapai

(iii) sekolah memiliki kepemimpinan yang kuat

(iv) adanya harapan yang tinggi dari personel sekolah (kepala sekolah, guru, dan staf lainnya termasuk siswa) untuk berprestasi

(v) adanya pengembangan staf sekolah yang terus menerus sesuai tuntutan IPTEK

(vi) adanya pelaksanaan evaluasi yang terus menerus terhadap berbagai aspek akademik dan administratif, dan pemanfaatan hasilnya untuk penyempurnaan/perbaikan mutu

(vii) adanya komunikasi dan dukungan intensif dari orang tua murid/masyarakat.

Pengembangan konsep manajemen ini didesain untuk meningkatkan kemampuan sekolah dan masyarakat dalam mengelola perubahan pendidikan kaitannya dengan tujuan keseluruhan, kebijakan, strategi perencanaan, inisiatif kurikulum yang telah ditentukan oleh pemerintah dan otoritas pendidikan. Pendidikan ini menuntut adanya perubahan sikap dan tingkah laku seluruh komponen sekolah; kepala sekolah, guru dan tenaga/staf administrasi termasuk orang tua dan masyarakat dalam memandang, memahami, membantu sekaligus sebagai pemantau yang melaksanakan monitoring dan evaluasi dalam pengelolaan sekolah yang bersangkutan dengan didukung oleh pengelolaan sistem informasi yang presentatif dan valid. Akhir dari semua itu ditujukan kepada keberhasilan sekolah untuk menyiapkan pendidikan yang berkualitas/bermutu bagi masyarakat.

Dalam pengimplementasian konsep ini, sekolah memiliki tanggung jawab untuk mengelola dirinya berkaitan dengan permasalahan administrasi, keuangan dan fungsi setiap personel sekolah di dalam kerangka arah dan kebijakan yang telah dirumuskan oleh pemerintah. Bersama - sama dengan orang tua dan masyarakat, sekolah harus membuat keputusan, mengatur skala prioritas disamping harus menyediakan lingkungan kerja yang lebih profesional bagi guru, dan meningkatkan pengetahuan dan kemampuan serta keyakinan masyarakat tentang sekolah/pendidikan.

Kepala sekolah harus tampil sebagai koordinator secara profesional harus terlibat dalam setiap proses perubahan di sekolah melalui penerapan prinsip-prinsip pengelolaan kualitas total dengan menciptakan kompetisi dan penghargaan di dalam sekolah itu sendiri maupun sekolah lain. 


\section{B. Perinsip-perinsip Pengelolaan}

Ada empat hal yang terkait dengan prinsip - prinsip pengelolaan kualitas total yaitu; (i) perhatian harus ditekankan kepada proses dengan terus - menerus mengumandangkan peningkatan mutu, (ii) kualitas/mutu harus ditentukan oleh pengguna jasa sekolah, (iii) prestasi harus diperoleh melalui pemahaman visi bukan dengan pemaksaan aturan, (iv) sekolah harus menghasilkan siswa yang memiliki ilmu pengetahuan, keterampilan, sikap arief bijaksana, karakter, dan memiliki kematangan emosional.

Sistem kompetisi tersebut akan mendorong sekolah untuk terus meningkatkan diri, sedangkan penghargaan akan dapat memberikan motivasi dan juga meningkatkan kepercayaan diri setiap personel sekolah, khususnya siswa. Jadi sekolah harus mengontrol semua sumber daya termasuk sumber daya manusia yang ada, dan lebih lanjut harus menggunakan secara lebih efisien sumber daya tersebut untuk hal - hal yang bermanfaat bagi peningkatan mutu khususnya. Sementara itu, kebijakan makro yang dirumuskan oleh pemerintah atau otoritas pendidikan lainnya masih diperlukan dalam rangka menjamin tujuan - tujuan yang bersifat nasional dan akuntabilitas yang berlingkup nasional (Nurkolis, 2006: 124).

\section{Tujuan Manajemen Berbasis Sekolah (MBS)}

\section{Tujuan Umum MBS :}

Memandirikan atau memberdayakan sekolah melalui pemberian otonomi kepada sekolah dan mendorong sekolah untuk melakukan pengambilan keputusan secara partisipatif.

\section{Tujuan Khusus MBS :}

a. Meningkatkan mutu pendidikan melalui kemandirian dan inisiatif sekolah dalam mengelola dan memberdayakan sumber daya yang ada.

b. Meningkatkan kepedulian warga sekolah dan masyarakat dalam penyelenggaraan pendidikan melalui pengambilan keputusan bersama.

c. Meningkatkan tanggung jawab sekolah kepada masyarakat.

d. Meningkatkan persaingan yang sehat antar sekolah tentang mutu pendidikan yang ingin dicapai.

\section{Konsep Dasar Manajemen Berbasis Sekolah (MBS)}

Menurut Umaedi (1999: 3) Konsep dasar Manajemen Berbasis Sekolah adalah manajemen yang bernuansa otonomi, kemandirian dan demokratis.

1. Otonomi, mempunyai makna bahwa kewenangan sekolah untuk mengatur dan mengurus kepentingan warga sekolah dalam mencapai tujuan sekolah (mutu pendidikan) menurut prakarsa berdasarkan aspirasi dan partisipasi warga sekolah dalam bingkai peraturan perundangan-undangan yang berlaku.

2. Kemandirian, mempunyai makna bahwa dalam pengambilan keputusan tidak tergantung pada birokrasi yang sentralistik dalam mengelola sumber daya yang ada, mengambil kebijakan, memilih strategi dan metoda dalam memecahkan persoalan yang ada, mampu menyesuaikan dengan kondisi lingkungan serta peka dan dapat memanfaatkan peluang yang ada.

3. Demokratif, mempunyai makna seluruh elemen-elemen sekolah di-libatkan dalam menetapkan, menyusun, melaksanakan dan meng-evaluasi. Pelaksanaan untuk mencapai tujuan sekolah (mutu pendidikan) sehingga memungkinkan tercapainya pengambilan kebijakan yang mendapat dukungan dari seluruh elemen-elemen warga sekolah.

\section{E. Karakteristik Manajemen Berbasis Sekolah (MBS)}

Karakterisitk Manajemen Barbasis Sekolah tentunya tidak terlepas dari pendekatan Input, Proses, Output Pendidikan (Nurkolis,2006: 204-205).

\section{Input Pendidikan}

a. Memiliki kebijakan, tujuan dan sasaran mutu yang jelas. 
b. Tersedianya sumber daya yang kompetitif dan berdedikasi.

c. Memiliki harapan prestasi yang tinggi.

d. Komitmen pada pelanggan.

2. Proses Pendidikan

a. Efekttivitas dalam proses belajar mengajar tinggi.

b. Kepemimpinan yang kuat.

c. Lingkungan sekolah yang nyaman.

d. Pengelolaan tenaga kependidikan yang efektif.

e. Tim kerja yang kompak dan dinamis.

f. Kemandirian, partisipatif dan keterbukaan (transparasi).

g. Evaluasi dan perbaikan secara berkelanjutan.

h. Responsif, antisipatif, komunikatif dan akuntabilitas.

3. Output yang diharapkan

Pada dasarnya output yang diharapkan merupakan tujuan utama dari penyelenggaraan pendidikan secara umum.

\section{F. Nilai Positif Penerapan Manajemen Berbasis Sekolah}

Penerapan Manajemen Berbasis Sekolah (MBS) menurut Suyanto (2008: 10) akan menghasilkan nilai positif bagi sekolah antara lain :

1. Sekolah lebih mengetahui kekuatan, kelemahan, peluang dan ancaman bagi sekolah yang bersangkutan sehingga sekolah dapat lebih mengoptimalkan pemanfaatan sumber daya yang ada.

2. Sekolah lebih mengetahui kebutuhan skala prioritas.

3. Pengambilan keputusan lebih partisipatif terutama dalam hal :

a. Menetapkan sasaran peningkatan mutu

b. Menyusun rencana peningkatan mutu

c. Melaksanakan rencana peningkatan mutu

d. Melakukan evaluasi pelaksanaan peningkatan mutu.

4. Penggunaan dana lebih efektif dan efisien sesuai dengan skala prioritasnya

5. Keputusan bersama lebih menciptakan transparasi dan demokrasi

6. Dapat lebih meningkatkan rasa tanggung jawab.

7. Menumbuhkan persaingan sehat sehingga diharapkan adanya upaya inovatif.

\subsection{Profesionalisme Guru Bimbingan dan Konseling}

\section{a. Kualifikasi dan Kompetensi Konselor}

Keberadaan konselor dalam sistem pendidikan nasional dinyatakan sebagai salah satu kualifikasi pendidik, sejajar dengan kualifikasi guru, dosen, pamong belajar, tutor, widyaiswara, fasilitator, dan instruktur (UU No. 20 Tahun 2003 Pasal 1 Ayat 6). Masing-masing kualifikasi pendidik, termasuk konselor, memiliki keunikan konteks tugas dan ekspektasi kinerja. Standar kualifikasi akademik dan kompetensi konselor dikembangkan dan dirumuskan atas dasar kerangka pikir yang menegaskan konteks tugas dan ekspektasi kinerja konselor.

Konteks tugas konselor berada dalam kawasan pelayanan yang bertujuan mengembangkan potensi dan memandirikan konseli dalam pengambilan keputusan dan pilihan untuk mewujudkan kehidupan yang produktif, sejahtera, dan peduli kemaslahatan umum. Pelayanan dimaksud adalah pelayanan bimbingan dan konseling. Konselor adalah pengampu pelayanan ahli bimbingan dan konseling, terutama dalam jalur pendidikan formal dan nonformal.

Sosok utuh kompetensi konselor mencakup kompetensi akademik dan profesional sebagai satu keutuhan. Kompetensi akademik merupakan landasan ilmiah dari kiat pelaksanaan pelayanan profesional bimbingan dan konseling. Kompetensi akademik merupakan landasan bagi pengembangan kompetensi profesional, yang meliputi: (1) memahami secara mendalam konseli yang dilayani, (2) menguasai 
landasan dan kerangka teoretik bimbingan dan konseling, (3) menyelenggarakan pelayanan bimbingan dan konseling yang memandirikan, dan (4) mengembangkan pribadi dan profesionalitas konselor secara berkelanjutan.

Unjuk kerja konselor sangat dipengaruhi oleh kualitas penguasaan ke empat komptensi tersebut yang dilandasi oleh sikap, nilai, dan kecenderungan pribadi yang mendukung. Kompetensi akademik dan profesional konselor secara terintegrasi membangun keutuhan kompetensi pedagogik, kepribadian, sosial, dan profesional.

Pembentukan kompetensi akademik konselor ini merupakan proses pendidikan formal jenjang strata satu (S-1) bidang Bimbingan dan Konseling, yang bermuara pada penganugerahan ijazah akademik Sarjana Pendidikan (S.Pd) bidang Bimbingan dan Konseling. Sedangkan kompetensi profesional merupakan penguasaan kiat penyelenggaraan bimbingan dan konseling yang memandirikan, yang ditumbuhkan serta diasah melalui latihan menerapkan kompetensi akademik yang telah diperoleh dalam konteks otentik Pendidikan Profesi Konselor yang berorientasi pada pengalaman dan kemampuan praktik lapangan, dan memperoleh sertifikat dengan gelar profesi Konselor, disingkat Kons.

\section{b. Trilogi Profesi Konselor}

Untuk menjadi profesional, profesional dalam bidang apapun, seseorang harus menguasai dan memenuhi ketiga komponen trilogi profesi, yaitu (1) komponen dasar keilmuan, (2) komponen substansi profesi, dan (3) komponen praktik profesi.

Komponen dasar keilmuan memberikan landasan bagi calon tenaga profesional dalam wawasan, pengetahuan, keterampilan, nilai dan sikap berkenaan dengan profesi yang dimaksud. Komponen substansi profesi membekali calon profesional apa yang menjadi fokus dan objek praktis spesifik pekerjaan profesionalnya. Komponen praktik mengarahkan calon tenaga profesional untuk menyelenggarakan praktik profesinya itu kepada sasaran pelayanan atau pelanggan secara tepat dan berdaya guna.

Konselor, yang adalah pendidik (UU No.20 Tahun 2003 Pasal 1 Butir 6), sebagai tenaga professional dituntut untuk menguasai dan memenuhi trilogi profesi dalam bidang pendidikan pada umumnya, khususnya bidang konseling, yaitu :

- Komponen Dasar Keilmuan : Ilmu Pendidikan

- Komponen Substansi Profesi : Proses pembelajaran terhadap pengem-bangan diri / pribadi individu melalui modus pelayanan konseling.

- Komponen Praktik Profesi : Penyelenggaraan proses pembelajaran terhadap sasaran pelayanan melalui modus pelayanan konseling.

\section{c. Kinerja Guru Pembimbing}

Dalam Makalah Prayitno (2008 dalam blog www.akhmad sudrajat.com) Kinerja (performance) adalah kemauan dan kemampuan melakukan suatu pekerjaan. Dalam kamus besar Bahasa Indonesia, kinerja diartikan sesuatu yang dapat dicapai, prestasi yang diperlihatkan, dan kemampuan kerja. Berdasarkan berbagai versi pengertian di atas, maka dapat diambil kesimpulan, kinerja adalah kemampuan melakukan pekerjaan yang dapat dilihat dan prestasi yang ditampilkan.

Tugas guru pembimbing adalah mengenal siswa dengan berbagai karakteristiknya, konseling perorangan, bimbingan dan konseling kelompok, melaksanakan bimbingan karir termasuk informasi pendidikan dan karir, penempatan, tindak lanjat dan penflaian, konsultasi dengan guru, semua personfl sekolah, orang tua, siswa, kelompok dan masyarakat.

Pada awal perkembangan BK di Indonesia, sampai diterbitkannya SK Menpan No 84 Tahun 1993. Kegiatan BK belum terpola, sehingga menimbulkan perbedaan persepsi tentang BK di sekolah. Sehubungan dengan itu Prayitno, dkk mengemukakan pelayanan BK di sekolah sebagai salah satu kesatuan, dinamakan 'BK Pola 17' yang sekarang berkembang dan dikenal dengan istilah BK 17 Plus, dimana ada penambahan 
pada bidang pelayanan BK, yaitu bidang pengembangan kehidupan berkeluarga dan pengembangan kehidupan keberagamaan, serta penambahan pada jenis layanan BK, yaitu layanan konsultasi dan mediasi.

Selanjutnya gagasan tersebut, diakui secara nasional dan dicantumkan dalam ketentuan resmi penyelanggaraan BK di sekolah-sekolah di Indonesia, yakni dalam SK Mendikbud No. 25 Tahun 1995 tentang petunjuk teknis ketentuan pelaksanaan jabatan fungsional guru dan angka kreditya. Tugas pokok guru pembimbing di sekolah, (1). Menyusun program bimbingan, yaitu rencana pelayanan BK dalam bidang bimbingan pribadi, belajar, bimbingan sosial, dan bimbingan karir; (2) melaksanakan program bimbingan, yaitu melaksanakan fungsi pelayanan pemahaman, pencegahan, pemeliharaan, dan pengembangan (pada BK 17 plus ditambah dengan rungsi advokasi) dalam setiap bidang pelayanan: (3) Evaluasi pelaksanaan BK; (4) analisis hasil evaluasi; dan (5) tindak lanjut

\section{d. Pengelolaan Kinerja Konselor untuk Meningkatkan Profesionalisme}

Menurut Prayitno (2008: 6) bahwa manajemen pengelolaan Kinerja Konselor pada dasarnya terfokus pada empat pilar kegiatan, yaitu perencanaan (planning-P), pengorganisasian (organizing-O), pelaksanaan (actuating-A), dan pengontrolan (controlling-C). Pengelolaan berbasis kinerja mendasarkan pelaksanaannya pada kinerja konselor berkenaan dengan POAC penyelenggaraan pelayanan konseling terhadap sasaran pelayanan yang menjadi tanggung jawabnya. Arah POAC adalah :

a. P: Bagaimana konselor membuat perencanaan layanan dan kegiatan pendukung, mulai dari membuat program tahunan, semesteran, bulanan, dan mingguan sampai dengan harian (berupa SATLAN dan SATKUNG).

b. O: Bagaimana konselor mengorganisasikan berbagai unsur dan sarana yang akan dilibatkan di dalam kegiatan. Unsur-unsur ini meliputi unsur-unsur personal (seperti peranan pimpinan sekolah, wali kelas, guru, orang tua), sarana fisik dan lingkungan (seperti ruangan dan mobiler, alat bantu seperti komputer, film, dan objek-objek yang dikunjungi), urusan administrasi, dana, dll.

c. A: Bagaimana konselor mewujudkan dalam praktik jenis-jenis layanan dan kegiatan pendukung melalui SPO masing-masing kegiatan yang telah direncanakan dan diorganisasikan.

d. C: Bagaimana konselor mengontrol praktik pelayanannya dalam bentuk penilaian hasil dan mempertanggungjawabkannya kepada stakeholders. Kegiatan ini melibatkan peran pengawasan dan pembinaan baik dari pihak interen maupun eksteren satuan pendidikan (lembaga kerja), serta organisasi profesi.

\subsection{Pergeseran Pola Manajemen dan Proses Bimbingan dan Konseling}

Sudrajat mensarikan adanya pergeseran pola manajemen dan proses bimbingan dan konseling dalam diagram dibawah ini

\begin{tabular}{|l|l|}
\hline \multicolumn{2}{|c|}{ Manajemen Bimbingan dan Konseling } \\
\hline $\begin{array}{l}\text { Pola Lama } \\
\text { benitikberatkan pada siswa yang }\end{array}$ & \multicolumn{1}{c|}{ Pola Baru } \\
\hline $\begin{array}{l}\text { Dilaksanakan karena adanya } \\
\text { krisis/masalah }\end{array}$ & Delayani seluruh siswa (guidance for all) \\
\hline Pendekatan panggilan (on call) & Terjadwal (kalender) \\
\hline $\begin{array}{l}\text { Disampaikan dan dilaksanakan hanya } \\
\text { oleh konselor }\end{array}$ & $\begin{array}{l}\text { Kolaboratif antara konselor, guru, orang } \\
\text { tua dan masyarakat }\end{array}$ \\
\hline $\begin{array}{l}\text { Dimiliki hanya oleh staf konseling } \\
\text { (konselor) }\end{array}$ & $\begin{array}{l}\text { Didukung dan dimiliki oleh seluruh } \\
\text { komunitas }\end{array}$ \\
\hline
\end{tabular}




\begin{tabular}{|l|l|}
\hline Mengukur jumlah usaha yang dilakukan & $\begin{array}{l}\text { Mengukur dampak yang dikaitkan dengan } \\
\text { tujuan }\end{array}$ \\
\hline $\begin{array}{l}\text { Berurusan dengan proses melaksanakan } \\
\text { pekerjaan }\end{array}$ & $\begin{array}{l}\text { Berurusan dengan pencapain tujuan, } \\
\text { sasaran dan hasil }\end{array}$ \\
\hline $\begin{array}{l}\text { Memfokuskan pada tujuan dan yang } \\
\text { dianggap baik }\end{array}$ & Memfokuskan pada pencapaian \\
\hline $\begin{array}{l}\text { Bekerja untuk memelihara sistem yang } \\
\text { ada }\end{array}$ & $\begin{array}{l}\text { Responsif dan beradaptasi dengan } \\
\text { perubahan }\end{array}$ \\
\hline $\begin{array}{l}\text { Membicarakan tentang bagaimana } \\
\text { bekerja keras }\end{array}$ & Membicarakan tentang efektivitas kerja \\
\hline
\end{tabular}

\begin{tabular}{|l|l|}
\multicolumn{2}{|c|}{ Proses Konseling } \\
\hline Bersifat klinis & Bersifat pedagogis \\
\hline Melihat kelemahan klien & Melihat potensi klien (siswa) \\
\hline $\begin{array}{l}\text { Berorientasi pemecahan masalah klien } \\
\text { (siswa) }\end{array}$ & $\begin{array}{l}\text { Berorientasi pengembangan potensi } \\
\text { positif klien (siswa) }\end{array}$ \\
\hline Konselor serius & Menggembirakan klien (siswa) \\
\hline $\begin{array}{l}\text { Dialog menekan perasaan klien dan klien } \\
\text { (siswa) sering tertutup }\end{array}$ & $\begin{array}{l}\text { Dialog konselor menyentuh klien (siswa), } \\
\text { klien (siswa) terbuka }\end{array}$ \\
\hline Klien sebagai obyek & Klien (siswa) sebagai subyek \\
\hline $\begin{array}{l}\text { Konselor dominan dan bertindak sebagai } \\
\text { problem solver }\end{array}$ & $\begin{array}{l}\text { Konselor hanya membantu dan memberi } \\
\text { alternatif-alternatif }\end{array}$ \\
\hline
\end{tabular}

\subsection{Potret Profesional Konseling di Sekolah}

Dalam setting sekolah guru pembimbing sampai saat ini secara jujur dan objektif haruslah kita akui belum dikatakan profesional apabila merujuk pada ketentuan profesional menurut undang-undang guru dan dosen. Sedangkan apabila dilihat dari unjuk kerjanya juga masih jauh dari yang diharapkan terutama ketidakmampuan dan ketidakberdayaan untuk menolak tugas-tugas yang di luar kewenangan dan tanggungjawab serta tugas pokoknya selaku konselor sekolah atau guru pembimbing. Masih banyak kita jumpai konselor sekolah yang ditugasi sebagai penjaga pintu gerbang, tukang absen, pencari pencuri dan perazia serta hal-hal atau tugas lain yang jelas tidak mencerminkan profesi konselor tetapi justru merusak dan memberikan citra buruk dan tindakan yang tidak disukai siswa. Belum lagi pandangan miring dan persepsi rekan atau kolega di sekolah yang menganggap bahwa guru pembimbing pekerjaan yang bisa dilakukan siapa saja terutama yang sudah tua dan tidak mempunyaai jam, pekerjaannya ringan gajinya sama, dan pandangan-pandangan miring lain yang sampai sekarang masih sering dijumpai, kita dengar dan kita rasakan.

Dapat dikatakan bahwa sebagai profesi, profesi konseling belum mendapat tempat yang sejajar dengan profesi lain di masyarakat. Padahal sebagai helping profession, profesi konseling berhak dan layak untuk berkiprah memberikan jasa dan layanan kepada masyarakat tanpa harus takut bersinggungan dengan wilayah profesi lain. Hal ini karena profesi konseling memiliki paradigma yang berbeda dengan profesi pemberi bantuan yang sejenis.

Persoalan lainnya yang mengemuka dan selalu mengundang diskusi adalah seputar kemartabatan konselor. Banyak kalangan yang masih mempertanyakan tentang kadar keprofesionalan para pelaku profesi konseling itu. Jangankan untuk setting masyarakat, di 
setting persekolahan tidak sedikit ditemukan pandangan-pandangan yang merendahkan tugas dan pekerjaan konselor sekolah. Semua itu tentu merupakan sesuatu yang seharusnya disikapi sebagai tantangan dalam upaya menegakkan kemartabatan profesi bimbingan dan konseling (Heru Mugiarso,2008: 3).

\section{MENINGKATKAN PROFESIONALISME GURU BIMBINGAN DAN KONSELING MELALUI MANAJEMEN BIMBINGAN DAN KONSELING BERBASIS SEKOLAH}

Departemen Pendidikan Nasional telah menggulirkan kebijakan pola manajemen pendidikan baru yang di dalamnya memuat kewenangan yang luas kepada sekolah untuk mengatur dan mengendalikan sekolah, dengan mendorong pengambilan keputusan partisipatif yang melibatkan langsung semua warga sekolah. Pola manajemen baru ini dikenal dengan istilah Manajemen Peningkatan Mutu Berbasis Sekolah atau disingkat MPMBS.

Implikasi MPMBS berkenaan dengan peningkatan profesionalisme bimbingan konseling di sekolah, dapat diperinci sebagai berikut : (1) Pemberdayaan dan Profesionalisme Konselor; (2) Akuntabilitas Kinerja Konselor; dan (3) Konselor Sebagai Agen Informasi

\section{Pemberdayaan dan Profesionalisme Konselor}

Manajemen Peningkatan Mutu Berbasis Sekolah (MPMBS) ditandai dengan adanya perubahan manajemen dari pendekatan sentralistik-birokratik menuju desentralistikprofesional. Sebagaimana dimaklumi bahwa dalam pendekatan sentralistik-birokratik, konselor dalam melaksanakan tugasnya sudah ditentukan dan dipolakan sedemikian rupa oleh pusat, melalui berbagai bentuk aturan, ketentuan, petunjuk pelaksanaan, petunjuk teknis dan sebagainya. Akibatnya, ruang gerak konselor menjadi terbatasi, sehingga pada akhirnya konselor menjadi kurang terbiasa dengan budaya kreatif dan inovatif.

Aturan dan ketentuan yang kaku dan ketat telah menggiring dan memposisikan konselor pada iklim kerja yang tidak lagi didasari oleh sikap profesinal, namun justru lebih banyak sekedar menjalankan kewajiban rutin semata. Maka, muncullah berbagai sikap yang kurang menguntungkan, seperti : malas, masa bodoh dan tidak peduli terhadap prestasi kerja.

Dengan hadirnya Manajemen Peningkatan Mutu Berbasis Sekolah (MPMBS), yang mengedepankan pendekatan desentralistik-profesional, maka ruang gerak konselor menjadi leluasa. Proses kreatif dan inovatif justru menjadi lebih utama. Konselor didorong untuk memiliki keberanian dan membiasakan diri untuk menemukan cara-cara baru yang lebih efektif dan efisien dalam melaksanakan berbagai kegiatan pelayanan bimbingan dan konseling. Dengan kata lain, memasuki alam Manajemen Peningkatan Mutu Berbasis Sekolah (MPMBS), konselor dituntut bekerja secara profesional.

Konselor seyogyanya tidak merasa cepat berpuas diri dengan kapasitas pengetahuan dan keterampilan yang saat ini dimilikinya, namun justru harus senantiasa berusaha untuk memutakhirkan pengetahuan dan keterampilannya. Bagaimanapun,dalam era informasi sekarang ini perkembangan ilmu pengetahuan dan teknologi dalam bimbingan konseling dari waktu ke waktu berkembang secara sangat pesat. Sehingga seorang konselor dituntut untuk terus dapat mengantisipasi arah perkembangan yang terjadi, agar tidak menjadi terpuruk secara profesional.

Upaya peningkatan kapasitas pengetahuan dapat dilakukan dengan berbagai cara, baik secara langsung maupun tidak langsung. Secara tidak langsung, bisa saja dilakukan melalui berbagai bacaan atau buku yang berhubungan dengan dunia bimbingan dan konseling, atau bahkan bila perlu dilakukan dengan cara melalui penjelajahan situs-situs dalam internet, yang memang banyak menyediakan berbagai informasi terkini, termasuk yang berhubungan dengan bimbingan dan konseling.

Sedangkan secara langsung, bisa dilakukan dengan cara melibatkan diri dalam berbagai aktivitas forum keilmuan, seperti : seminar, penataran dan pelatihan, atau mengikuti kegiatan MGP seperti sekarang ini. Bahkan, akan lebih baik jika timbul kemauan untuk berusaha menuntut ilmu melalui jenjang pendidikan formal. 
Sedangkan untuk meningkatkan keterampilan berbagai teknik bimbingan, salah satu cara yang dipandang cukup efektif adalah dengan berusaha secara terus menerus dan seringkali mempraktekkan berbagai teknik yang ada. Misalkan, untuk menguasai teknikteknik konseling, tentunya konselor harus mempraktekkan sendiri secara langsung, dan setiap setelah selesai mempraktekkan, diikuti dengan evaluasi terhadap apa yang telah dilakukan. Kemudian, membandingkannya dengan keharusan-keharusan berdasarkan teori yang ada, sehingga akan bisa diketahui kelemahan dan keunggulan dari praktek yang telah dilakukan. Memasuki tahap praktek konseling berikutnya tentunya sudah disertai usaha perbaikan, dengan bercermin dari kekurangan- kekurangan pada praktek konseling sebelumnya.

\section{Akuntabilitas Kerja Konselor}

Memasuki alam Manajemen Peningkatan Mutu Berbasis Sekolah (MPMBS), dengan sendirinya akuntabilitas konselor semakin luas, tidak hanya dihadapan kepala sekolah ataupun pengawas, namun mencakup seluruh stake holder dalam bidang pendidikan, terutama masyarakat dan orang tua siswa. Bagaimanapun masyarakat, khususnya orang tua siswa telah rela berkorban mengeluarkan sejumlah dana untuk kepentingan pendidikan anaknya. Wajar kalau mereka menuntut pertanggungjawaban kepada sekolah dan kepada konselor khususnya atas hasil-hasil kerja yang telah dilakukan, demi keberhasilan dan kemajuan peserta didik.

Dengan adanya akuntabilitas ini, jelas konselor dituntut untuk lebih meningkatkan mutu kinerja dan tingkat produktivitas dalam memberikan layanan bantuan terhadap para siswa. Jika hal ini tidak terpenuhi maka konselor harus bersiap-siap untuk menerima berbagai complain dari masyarakat yang mungkin tidak mengenakkan.

\section{Konselor Sebagai Agen Informasi}

Penerapan Manajemen Peningkatan Mutu Berbasis Sekolah (MPMBS) ditandai dengan adanya kewenangan sekolah dalam mengambil keputusan. Oleh karena itu, konselor seyogyanya dapat berusaha melibatkan diri dalam berbagai proses pengambilan keputusan. Karena, bagaimanapun konselor bisa dianggap sebagai "orang yang paling banyak tahu" tentang keadaan siswanya secara personal. Dengan kata lain, konselor dianggap sebagai orang yang memiliki informasi atau data tentang siswa yang lebih lengkap dan memadai.

Informasi atau data tentang siswa ini ini sangat berguna dan dapat dijadikan dasar untuk berbagai pengambilan keputusan sekolah yang berkenaan dengan siswa. Oleh sebab itu, informasi harus diadministrasikan sedemikian rupa dan siap saji (ready for use), kapan saja diperlukan. Atau secara kreatif, konselor dapat menciptakan berbagai software tentang bimbingan dan konseling sesuai dengan kebutuhan kerja, yang sekiranya dapat membantu mempermudah pengadministrasian dan penyajian data. Dengan sendirinya, dalam hal ini konselor dituntut untuk memahami dan menguasai teknologi komputer.

Satu hal lagi bahwa dalam penerapan Manajemen Peningkatan Mutu Berbasis Sekolah (MPMBS), upaya meningkatkan kuantitas dan kualitas layanan bimbingan ini konselor hendaknya memperhatikan pengembangan kerja sama, koordinasi dan sinergis kerja dengan berbagai komponen pendidikan lainnya. Karena dalam penerapan Manajemen Peningkatan Mutu Berbasis Sekolah (MPMBS), keberhasilan pendidikan di sekolah tidak lagi didasarkan pada individual yang cerdas, akan tetapi sangat mengutamakan pada team work. Untuk itulah, konselor sedapat mungkin harus menjadi bagian utama dari team work tersebut (Sudrajat, 2008).

\section{KESIMPULAN}

a. Manajemen peningkatan mutu berbasis sekolah merupakan alternatif baru dalam pengelolaan pendidikan yang lebih menekankan kepada kemandirian dan kreatifitas sekolah. Manajemen Peningkatan Mutu Berbasis Sekolah (MPMBS) merupakan proses pengintegrasian, pengkoordinasian dan pemanfaatan dengan melibatkan secara menyeluruh elemen-elemen yang ada pada sekolah untuk mencapai tujuan (mutu pendidikan) yang diharapkan secara efisien. 
b. Dengan hadirnya Manajemen Peningkatan Mutu Berbasis Sekolah, yang mengedepankan pendekatan desentralistik-profesional, maka ruang gerak konselor menjadi leluasa. Proses kreatif dan inovatif justru menjadi lebih utama. Konselor didorong untuk memiliki keberanian dan membiasakan diri untuk menemukan cara-cara baru yang lebih efektif dan efisien dalam melaksanakan berbagai kegiatan pelayanan bimbingan dan konseling. Dengan kata lain, memasuki alam Manajemen Peningkatan Mutu Berbasis Sekolah (MPMBS), konselor dituntut bekerja secara profesional.

c. Kenyataannya di lapangan pekerjaan bimbingan dan konseling kerapkali dipandang sebelah mata oleh orang-orang yang justru memiliki kepentingan dengan bimbingan dan konseling itu sendiri, Misalnya, oleh siswa, guru mata pelajaran, kepala sekolah, para pemegang kebijakan lainnya atau masyarakat. Tidak sedikit mereka yang beranggapan bahwa konselor atau guru Bimbingna dan Konseling di sekolah hanya makan gaji buta, tidak jelas kerjanya, atau hanya dianggap sebagai pekerjaan embel-embel saja. Ungkapan-ungkapan miring semacam itu bisa ditepis jika saja konselor atau guru Bimbingan dan Konseling yang bersangkutan dapat menunjukkan kinerjanya sekaligus mampu melakukan advokasi di hadapan mitra-mitra kerjanya di sekolah.

d. Banyak kalangan yang masih mempertanyakan tentang kadar keprofesionalan para pelaku profesi konseling itu. Jangankan untuk setting masyarakat, di setting persekolahan tidak sedikit ditemukan pandangan-pandangan yang merendahkan tugas dan pekerjaan konselor sekolah. Semua itu tentu merupakan sesuatu yang seharusnya disikapi sebagai tantangan dalam upaya menegakkan kemartabatan profesi bimbingan dan konseling

e. Dalam setting sekolah konselor sekolah atau guru pembimbing sampai saat ini secara jujur dan objektif haruslah kita akui belumlah dikatakan profesional apabila merujuk pada ketentuan profesional menurut undang-undang guru dan dosen. Sedangkan apabila dilihat dari unjuk kerjanya juga masih jauh dari yang diharapkan terutama ketidakmampuan dan ketidakberdayaan untuk menolak tugas-tugas yang di luar kewenangan dan tanggungjawab serta tugas pokoknya selaku konselor sekolah atau guru pembimbing. Masih banyak kita jumpai konselor sekolah yang ditugasi sebagai penjaga pintu gerbang, tukang absen, pencari pencuri dan perazia serta hal-hal atau tugas lain yang jelas tidak mencerminkan profesi konselor tetapi justru merusak dan memberikan citra buruk dan tindakan yang tidak disukai siswa. Belum lagi pandangan miring dan persepsi rekan atau kolega di sekolah yang menganggap bahwa guru pembimbing pekerjaan yang bisa dilakukan siapa saja terutama yang sudah tua dan tidak mempunyaai jam, pekerjaannya ringan gajinya sama, dan pandangan-pandangan miring lain yang sampai sekarang masih sering dijumpai, kita dengar dan kita rasakan.

\section{SARAN}

a. MPMBS yang mengedepankan pendekatan desentralistik-profesional, maka konselor dituntut bekerja secara profesional. Hal-hal apa yang perlu disiapkan untuk menuju ke arah profesionalisme tentu saja konselor seyogyanya dapat berusaha mengembangkan secara terus menerus kapasitas pengetahuan dan keterampilan yang dimilikinya, yang justru merupakan prasyarat untuk menjadi seorang profesional.

b. Konselor seyogyanya tidak merasa cepat berpuas diri dengan kapasitas pengetahuan dan keterampilan yang saat ini dimilikinya, namun justru harus senantiasa berusaha untuk memutakhirkan pengetahuan dan keterampilannya. Bagaimanapun,dalam era informasi sekarang ini perkembangan ilmu pengetahuan dan teknologi dalam bimbingan konseling dari waktu ke waktu berkembang secara sangat pesat. Sehingga seorang konselor dituntut untuk terus dapat mengantisipasi arah perkembangan yang terjadi, agar tidak menjadi terpuruk secara profesional.

c. Upaya peningkatan kapasitas pengetahuan dapat dilakukan dengan berbagai cara, baik secara langsung maupun tidak langsung. Secara tidak langsung, bisa saja dilakukan melalui berbagai bacaan atau buku yang berhubungan dengan dunia bimbingan dan konseling, atau 
bahkan bila perlu melalui penjelajahan situs-situs dalam internet, yang banyak menyediakan berbagai informasi terkini, termasuk yang berhubungan dengan bimbingan dan konseling.

d. Bagi konselor yang berlatar belakang pendidikan program studi bimbingan, barangkali tidak ada salahnya untuk berusaha menempuh pendidikan lanjutan pada jenjang yang lebih tinggi. Sementara, bagi kawan-kawan konselor yang kebetulan bukan berlatar belakang pendidikan bimbingan, dalam rangka memantapkan diri sebagai konselor, tidak ada salahnya pula untuk mencoba terjun menekuni dunia akademis dalam bimbingan dan konseling. Sehingga pada gilirannya, dalam melaksanakan berbagai tugas bimbingan, konselor benar-benar telah ditopang oleh fundasi keilmuan yang mantap dan memadai.

e. Sedangkan untuk meningkatkan keterampilan berbagai teknik bimbingan, salah satu cara yang dipandang cukup efektif adalah dengan berusaha secara terus menerus dan seringkali mempraktekkan berbagai teknik yang ada. Misalkan, untuk menguasai teknik-teknik konseling, tentunya konselor harus mempraktekkan sendiri secara langsung, dan setiap setelah selesai mempraktekkan, diikuti dengan evaluasi terhadap apa yang telah dilakukan. Kemudian, membandingkannya dengan keharusan-keharusan berdasarkan teori yang ada, sehingga akan bisa diketahui kelemahan dan keunggulan dari praktek yang telah dilakukan. Memasuki tahap praktek konseling berikutnya tentunya sudah disertai usaha perbaikan, dengan bercermin dari kekurangan- kekurangan pada praktek konseling sebelumnya.

f. Hal ini secara terus menerus dilakukan dari satu praktek konseling ke praktek konseling berikutnya, dan sebaiknya disertai pula dengan pencatatan terhadap apa-apa yang telah dilakukan yang dapat dimanfaatkan sebagai bahan refleksi sekaligus sebagai bukti fisik dari usaha ilmiah. Berbekal kesabaran dan ketekunan, usaha ini niscaya pada akhirnya akan dapat mengantarkan sampai pada taraf yang dikehendaki. Walaupun demikian perlu dicatat, bahwa keleluasaan dalam menjalankan tugas ini tidak diartikan segala sesuatunya menjadi serba boleh, hal-hal yang menyangkut prinsip dan etika profesi bimbingan tetap harus dijaga dan dipelihara, sejalan dengan tuntutan profesionalisme.

\section{DAFTAR PUSTAKA}

Mugiarso, Heru, Kemartabatan Konselor, Makalah disampaikan pada Seminar Nasional “ Konselor Bermartabat”, Universitas Muria Kudus, 9 Agustus 2008.

Umaedi, 1999, Manajemen Peningkatan Mutu Berbasis Sekolah : SebuahPendekatan Baru dalam Pengelolaan Sekolah Untuk Peningkatan Mutu, Jakarta, Departemen P \& K Direktorat Jenderal Pendidikan Dasar dan Menengah

Nurkolis, 2006, Manajemen Berbasis Sekolah : Teori, Model dan Aplikasi,Jakarta: Grasindo

Sudrajat, Akhmad, 2008, Bimbingan Konseling dan Manajemen Peningkatan Mutu Berbasis Sekolah, www.Akhmad Sudrajat.com

Suyanto 2008, Perumusan Manajemen Berbasis Sekolah, dalam Blogg www.Akhmad Sudrajat,com

PERMENDIKNAS Nomor 27 Tahun 2008, Tentang : Standar Kualifikasi Akademik dan Kompetensi Konselor

Prayitno, 2008, Trilogi Profesi Konselor dan Pengelolaan Berbasis Kinerja, www.konselingindonesia,com 
